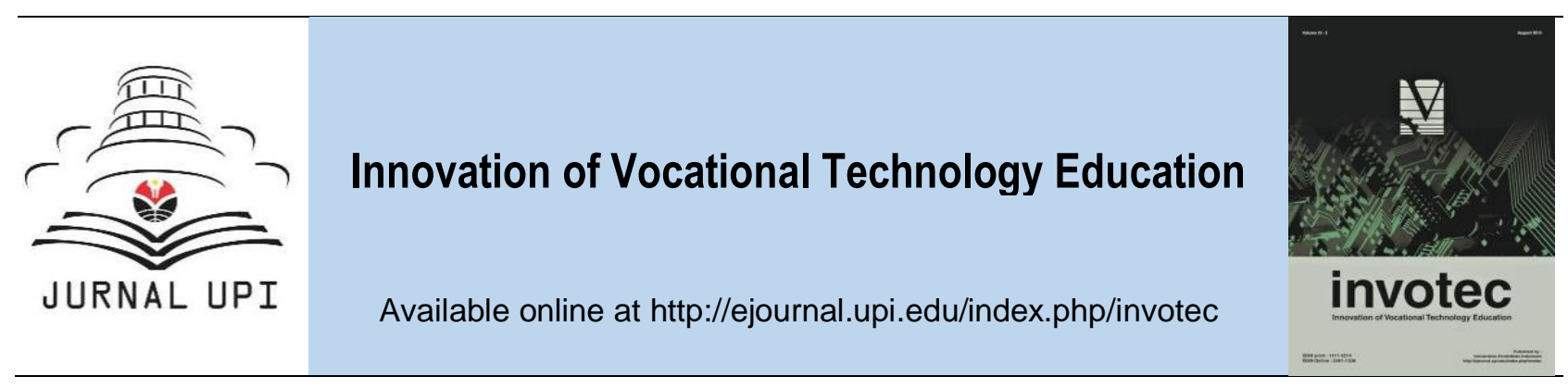

\title{
Design and Developement Multimedia Animation Corrosion and Coating Process
}

\author{
Y. Sukrawan, E. Permana, M. Komaro \& A. Solehudin \\ Universitas Pendidikan Indonesia, Indonesia
}

\section{ARTICLE INFO}

Article history:

Received 21 November 2017

Received in revised form 22 December 2017

Accepted 3 January 2017

Available online 28 February 2017

Keywords:

Animation-based multimedia

Corrosion process

Coating process

Corresponding author:

yusepsukrawan@upi.edu
A B S T R A C T

The purpose of this research is to create an animation-based learning media of corrosion processes in the subject of corrosion and coating. The media produced is a learning media program in the form of .swf file that can be directly installed and accessed on personal computer. This development research (R\&D) was started with concept exploration to find out the necessary product model, followed by its development through many test steps (expert judgment, limited test, and application test) and correction procedure until the proper product was determined. The last step was an experimental process to validate the product. The research has result an animationbased interactive media which has good criteria according to the media expert judgment value of $78.3 \%$, students' response of $83.0 \%$ and subject matter expert judgment value of $89.0 \%$. Validity test show that the media has a significant effect to increase a number of students who reach minimum standard competency.

\section{Introduction}

In the field of education, the technology required to deliver instructional materials to make it more attractive, especially the students' attention. In the learning process of learning media is one of the important elements as determinants of the quality of learning outcomes. Instructional media needed for teaching materials presented can be understood by the learner. Media develops computer-based learning every time, it is appropriate to help the learning process in order to produce optimal quality of learning. Media computer-based learning with a variety of images, text, sound video (multimedia), is expected to stimulate learners so as to improve the quality of learning.

The use of interactive multimedia CD-ROM is more effective with a variety of learning activities than is presented through the print media face to face and instead presented over the web with online learning (Dikshit et. al. 2013). Utilization of interactive multimedia (MMI) has been shown to improve the generic skills and problem-solving science teacher candidates SMK. As for the use of multimedia animation (MMA) has been shown to improve the reading skills of vocational students projected image (Anam et. al. 2009), can improve learning outcomes competence of the assembly and installation of the brake system of vocational students (Harsono and Samsudi, 2009).

Multimedia learning is widely used because it has many advantages a picture is better than words, animation is better than a still, sound is better than silence (Dahlqvist and Robert 1998:1). 
Twenty-value learning with multimedia or video in the classroom, which potentially can be produced, namely: 1) take care of students; 2) focus the concentration of students; 3) interested in learning in the classroom; 4) create a sense of anticipation; 5) provide energy by relaxing for students to practice learning; 6) adding the imagination of students; 7) enhance the supportive attitude and learning materials; 8) building relationships with other students and instructors; 9) increase the memory of the material; 10) improve understanding; 11) helps develop creativity; 12) stimulate the flow of ideas; 13) helps develop a deeper learning; 14) provides an opportunity for freedom of expression; 15) helps to collaborate; 16) inspire and motivate students; 17) makes learning fun; 18) set the right mood / comfortable; 19) Reduce anxiety and tension on topics that scary; and 20) create a visual image so impressive (Berk, 2009).

The development of learning tools are currently available and easier to use, so the trend of teachers to design and implement their own homemade animation will continue berlanjut.Tren this development is combined with a broader understanding of how these tools can help the learning process so that the use of animation and simulations in the classroom will continue to grow (Falvo, 2008). The use of multimedia in learning is very helpful learning (Munir and Zaman, 1998). Animation were previously shown to promote understanding and improve learning (Yarden and Yarden, 2006:33).

As a complete media, multimedia-enabled technology to develop the power of imagination, creativity, fantasy and emotions of children to a better direction. Student learning outcomes following the use of multimedia applications based computer network topology learning Macromedia Flash to experience a higher increase compared with the results of student learning without the use of multimedia applications based learning Macromedia Flash.

When having a media that can explain in detail about the corrosion can facilitate students understand the topic. Therefore the use of multimedia will try to improve learning achievement for student achievement is a measure of success in a study. The learning process using multimedia animation primary objective is to be closer to the actual conditions, especially in this case for this type of simulation.

\section{Method}

This research was conducted according to procedures of research and development method. The research was started by observation to find out a required research product followed by product development through some testing steps (experts' judgment, limited tests, and filed tests), product revision process, and finally validation step by product experiments.

First step of the research was to build animation-based media of corrosion using adobe flash software. The steps of the animation creation were: determination of corrosion subject matters to be animated (data collection, identification, and analyses), storyboard making (storyboard writing, material organizing, audio designing, editing, and proofreading), computer programming (using adobe flash-8), evaluation and development procedure through focus group discussion with media experts and subject experts.

Second step of the research was to perform product testing. It consisted of limited testing to a small number of students, boarder testing to medium number of students, field testing to find out any feedbacks to revise the product, validity testing by quasi-experiment, and implementation in lecturing corrosion and coating. Data collection was carried out by documentation study, observation, questioner, interview, and test. It was then analyzed qualitatively and quantitatively. According to research and development method, some research steps were conducted as follow:

a. Undergoing preliminary study of course syllabus of corrosion and plating at Department of Mechanical Engineering Education.

b. Designing and developing animation program according to the course syllabus. It consisted of arranging the selected material course frame by frame, storyboard making (setting, organizing, audio planning, editing, and proofreading), computer programming, and product evaluating through experts' judgment.

c. Limited testing of the developed animation-based multimedia. The media was tested by implementing it in a small group of students. Respond and feedback from the students were taken out and analyzed to revise it.

d. Validating the media. Validity testing was carried out through quasy-experiment research in which two groups of students were treated in different class. First group took a course conducted 
with the animation media and the second group was conducted course without using the animation. The evaluation results after the course were compared and analyzed to find out the difference.

\section{Result and Discussion}

Analyses stage was started by undertaking observation at the Department of Mechanical Engineering Education UPI Bandung to look for teaching method, media, lecturing course, and learning facilities. The data was collected by directly watching learning activities in classroom during lecturing process. The learning process was conducted in conservative way in which the lecture used traditional medias such as whiteboard, pictures (still images), and diagram instead of using more interactive ones although the learning facilities such as overhead projector and computer have been completed. Thus it can be said that the available facilities have not been optimally utilized and the use of animation-based multimedia is one of the effort to overcome.

One of the demands of the coarse syllabus of corrosion and coating is students must master the basic concepts of how the occurrence process of corrosion on metal, classification, and prevention of corrosion. The material in the form of the basic concept that must be understood before studying material corrosion on a higher level. The nature of the course requires students to be able to illustrate the movement of ions on metal that causes the onset of corrosion before they can understand it as a whole. The movement of ions is the abstract of course can not be delivered only by using still images and media will be better when depicted with a movement that resembles the real movement of the ions. For that use animation as a media can be an alternative that can be used as a media of learning. The development of interactive multimedia based animation made as attractive as possible to the research and development method are expected to display the material interestingly so that students are motivated and able to describe the actual events. Especially about the process of corrosion and metal coating which should be presented attractively in order to be easily understood.

The design stage is a process of making the design of interactive multimedia-based animation with reference to the syllabus. An interactive multimedia-based animation of the corrosion aprocess based on the results of the analysis of the syllabus was developed. The animation describes the process of corrosion on metal, causes and different types of corrosion.

The design phase is composed of three activities: preparation of the flowchart, storyboards, and interface design.

1. Flow Diagram (flowchart). Flowchart-based interactive multimedia animation can be seen in Figure 1.

2. Storyboard. Storyboard is a design of the animation in each part, from the sound up to the multimedia animation. Storyboards are used as a reference for the development of Interactive Multimedia design-based animation.

3. Interface design. The Interface of the media was made with a simple design that makes it easy for users to find the buttons as navigation from one frame to another frame. The interface design consits of of two parts namely the main menu interface design and interface design submission material. The main menu interface design is the main view interactive multimediabased animation that serves as the main navigator to explore multimedia features on the whole, while the material submission interface is displayed simply with a little button, because this material rely on animation movement and sound to make users focus on the material.

The stage of development of interactive multimedia based animation was begun by making the interface as a reference the layout of components, and astoryboard as a refernce of animation and multimedia navigation to move from one frame to another frame. The interface consists of main menu interface and interface of material in the form of animation.

Main menu display interface on interactive multimedia-based animation is shown in Figure 2. On this main menu interface, the object that is created is an object in the form of navigation buttons to move to the display according to its name. The name of the keys are: profiles that describe the media creators, objectives explain the direction of the learning process, materi contains the animated process of metal corrosion, the exercise as a means of evaluation after viewing this multimedia display and message from the maker. It also contains graphs and text describing the corrosion of the metal as a background on this interface. The display interface of material is shown 
in Figure 3. On this material interface there is an animation of corrosion complated by sound that accompanies the animation. When we press the play button then the animation will begin and it will stop if we press the stop button. Made also a button so that you can restore preview display as well as navigation buttons to explain the matter.



Figure 1. Flowchart of animation-based multimedia of corrosion

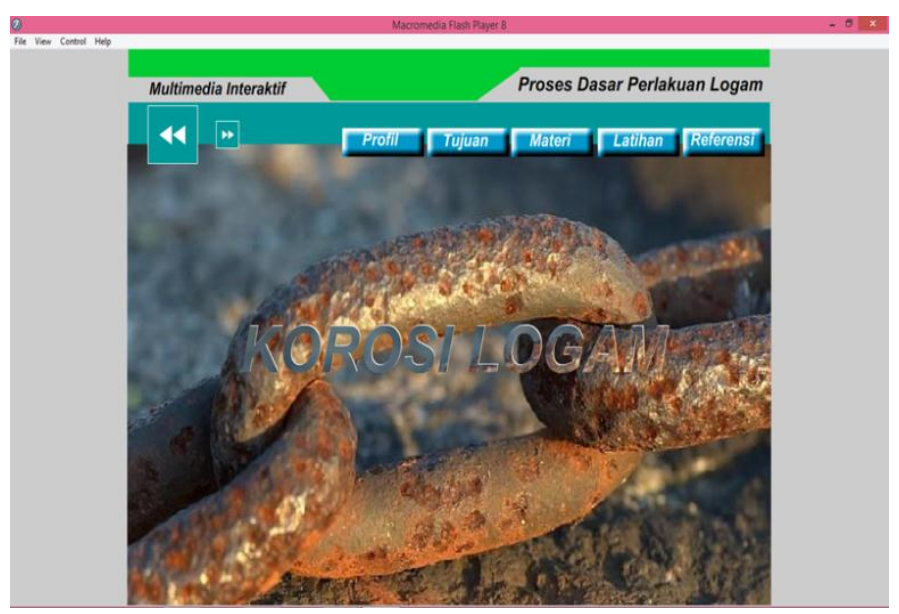

Figure 2 Main menu display

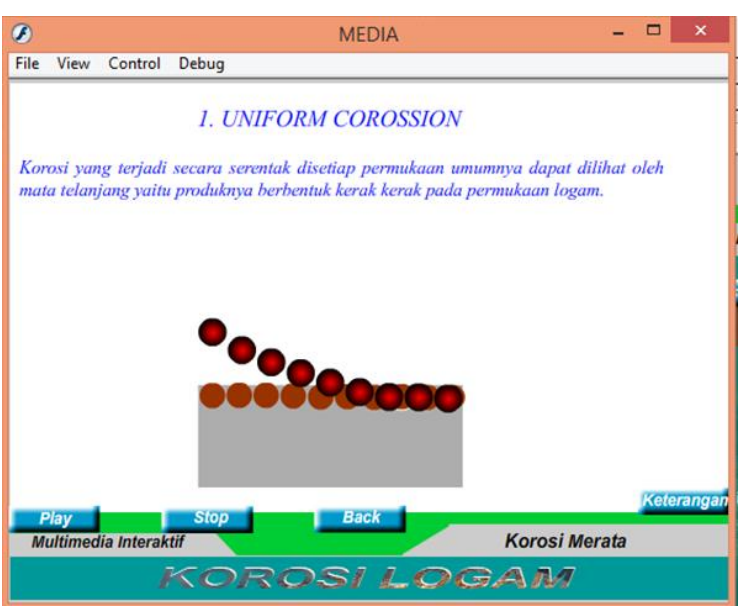

Figure 3. Material display

Multimedia testing phase was carried out by several stages, namely: testing by media experts, testing by experts and material testing by users of multimedia. Stage testing done before the multimedia in production so that when things are not in compliance can be revised first. Data obtained from the testing was material judgment by corrosion experts, media judgment by animation experts and users' data response. Description of the data, namely as follows. 
Judgment data by media expert in the research is to assess the information in terms of multimedia design judged by senior lecturers UPI. Judgment by media expert is intended to test the validity of the construction in terms of multimedia design. Judgment data is used as the foundation that multimedia animations viable for use in research. If the multimedia animation is already viable use, then multimedia animation that has been made can be said to be valid in terms of multimedia design. Sheet format by media expert judgment made on this measurement has scale-shaped research rating scale consisting of 15 gain statement.

Table 1. Data of media expert judgment.

\begin{tabular}{ccccccc}
\hline \multirow{3}{*}{ Accusition } & \multicolumn{5}{c}{ Mark } & \\
\cline { 2 - 6 } & 4 & 3 & 2 & 1 & 0 & Total \\
& $(\mathrm{SL})$ & $(\mathrm{L})$ & $(\mathrm{KL})$ & $(\mathrm{TL})$ & $(\mathrm{STL})$ & \\
\hline Summation & 2 & 13 & 0 & 0 & 0 & 15 \\
\hline Score & 8 & 39 & 0 & 0 & 0 & 47 \\
\hline \multicolumn{6}{c}{ Maximum score } & 60 \\
\hline \multicolumn{6}{c}{ Procentage (\%) } & 78.3 \\
\hline
\end{tabular}

The percentage (Table 1 ) of the feasibility of multimedia animation corrosion is of $78.3 \%$. The percentage of this animated multimedia is compared to proprietary percentage to get area eligibility for multimedia animation where a percentage of $78.3 \%$ are at the interval with good criteria. User response data in the research is to assess the students ' response description of multimedia-based animations which were filled by students majoring in mechanical engineering education. Student response sheet format created on this scale-shaped research rating scale consisted of 10 round statement. This statement concerned the use of multimedia in the development of interactive multimedia based animation competence corrosion and coating of metals.

The student response data aims to find out how interestingly interactive multimedia-based animation. Student interest in interactive multimedia-based animations can make it convenient to use in teaching and learning. Data response were given to 30 students who had seen the animation-based interactive multimedia competency corrosion and coating of metals.

Table 2. Data of user response

\begin{tabular}{ccccccc}
\hline \multirow{3}{*}{ Accusition } & \multicolumn{5}{c}{ Remark } & \multirow{2}{*}{ Total } \\
\cline { 2 - 6 } & $\begin{array}{c}4 \\
(\mathrm{SL})\end{array}$ & $\begin{array}{c}2 \\
(\mathrm{~L})\end{array}$ & $\begin{array}{c}1 \\
(\mathrm{KL})\end{array}$ & $\begin{array}{c}0 \\
(\mathrm{TL})\end{array}$ & $(\mathrm{STL})$ & \\
\hline Respondents & 13 & 15 & 1 & 1 & 0 & 30 \\
\hline Score & 520 & 450 & 20 & 10 & 0 & 1,000 \\
\hline \multicolumn{8}{c}{ Maximum score } & 1,200 \\
\hline \multicolumn{6}{c}{ Procentage (\%) } & 83.0 \\
\hline
\end{tabular}

The results of student responses (Table 2) describes average interest of students towards interactive multimedia-based animation of $83.0 \%$, this percentage categorized high or when compared with the requirement of the interval of student interest then there is the percentage value in the categories of 'interesting'. Interactive multimedia-based animation has advantages including the learning process interesting, students become motivated and able to achieve learning objectives. The media learning function in the learning process will further draw attention so as to cultivate motivation of study and learning materials will more clear its meaning so that it can be better understood by students and enable it to achieve the goals of learning.

This interest is due to the background in design view by interactive animation-based multimedia is very simple and the selection of the colour is appropriate as shown in Figure 3. In that picture, the onset of corrosion processes on metal is clearly aired with animation, to make it easier for the user, a singlebutton that can be pressed by the cursor starts moving animation and 
sound, stop button stops the animation in motion and sound, and there is a back button to go back and button captions to describe the animation in the show. All the buttons above are avaliable in every menu of subject matter display.

The result of the media experts judgment showed the feasibility of the media reached $78.3 \%$, that is, deserves to be used but with improvements. The improvements included addition of the symbol of every picture and using clearer narrative sound. After repairing, the animation-based interactive multimedia was used in the learning process. Pictures interface has significant improvements that can be seen from how it looks more attractive after the repair. In the repaired picture the display background color was made in difference color with the animation and so it looks more contrast. Navigation buttons were added to make it more user-friendly.

Subject matter expert judgment undertaken before the media expert validation showed that procentage of $89 \%$ with a very worthy categories. The matter needed no improvements and additions then the interactive animation-based multimedia is worth implemented. Before the process of application of the media, researchers first tried to test with the student response. Response was given after students had looked through the media during learning process by filling a statement sheet of student opinions. They include: level of media atractivenes, the way to operate the media, material contained therein, as well as the look and sound of the narrative. Media response of the students indicated that $83.0 \%$ of them have a good opinion the animation media which means that it attracts students once after they saw it.

After trying to use the multimedia animation in learning process, the students got increased learning results. Number of students reached minimum competency level increased to $73,91 \%$ (before $40 \%$ ) with an average value of 80.43 points. These results indicate that the use of interactive multimedia based animations can improve the results of the study.

Based on the description of the research data it can be stated that interactive multimediabased animation is capable to improve the learning results and grow multiple motivations. The use of teaching media in the teaching and learning process can arouse desire and interest in the new, demotivating and evoking stimuli and learning activities, and even psychological influences brought against students (Arsyad, 2013, p.19).

\section{Conclusion}

The conclusions can be obtained as follows: the animation-based multimedia of corrosion developed in the research has good criteria and deserve to be used in teaching and learning activities in vocational institutions of engineering. The results of the study by using the multimedia animation of corrosion contributed to an increase in the number of students who achieved the minimum standard of competency from $40 \%$ to $73.91 \%$.

\section{References}

Anam C., Khumaedi M., and Basyirun. (2009). Pembelajaran Ceramah dengan Media Animasi untuk Mengingkatkan Kemampuan Siswa Dalam Membaca Gambar Proyeksi. Jurnal Pendidikan Teknik Mesin, 9(1), p.7-13.

Arsyad, A. (2013). Media Pembelajaran. Jakarta: PT. Raja Grafindo Persada.

Berk, R. A. (2009). Multimedia teaching with video clips: TV, movies, YouTube, and mtv in the college classroom. International Journal of Technology in Teaching and Learning, 5(1), p.1-21.

Dahlqvist P, and Robert, R. (1998). Using Animations in Educational Software. A Pilot Study of 7th Grade Students. Department of Computer and Systems Sciences, Stockholm University, Stockholm, Sweden.

Dikshit J, Garg, S., and Panda, S. (2013). Pedagogic Effectiveness of Print, Interactive Multimedia, and Online Resources: A Case Study of IGNOU. International Journal of Instruction, 6 (2), p.193-210. 
Falvo, D.A. (2008). Animations and simulations for teaching and learning molecular chemistry. International Journal of Technology in Teaching and Learning. 4(1). p. 68-77.

Harsono, B. S., and Samsudi. (2009). Perbedaan Hasil Belajar antara Metoda Ceramah Konvensional dengan Ceramah Berbantuan Media Animasi pada Pembelajaran Kompetensi Perakitan dan Pemasangan Sistem Rem. Jurnal Pendidikan Teknik Mesin, 9(2), p.71-79.

Munir dan Zaman, H. B. (1998). Aplikasi Multimedia dalam Pendidikan. Jurnal BTP. Fakulti Teknologi dan Sains Maklumat Universiti Kebangsaan Malaysia.

Yarden A, dan Yarden H. (2006). Supporting learning of biotechnological methods using interactive and task included Animations. SIG 2 Bi-Annual meeting, "Text and Graphics Comprehension". $30^{\text {th }}$ of Augst - $1^{\text {st }}$ September 2006. University of Nottingham. (19). 